\title{
Synthesis and Structural Properties of Copper(II), Nickel(II) and Cobalt(II) Complexes with 2,4-Furyliminobenzylacetophenone
}

\author{
Jagvir Singh $^{1}$ and Prashant Singh ${ }^{2}$ \\ ${ }^{1}$ Meerut College, CCS University, Meerut 250001, India \\ ${ }^{2}$ B.B.A. University, (A Central University) of Lucknow, Lucknow 226025, India \\ Correspondence should be addressed to Jagvir Singh, singhjagvir0143@gmail.com
}

Received 7 May 2012; Accepted 26 May 2012

Academic Editors: J. G. Han and E. B. Starikov

Copyright ( $) 2012$ J. Singh and P. Singh. This is an open access article distributed under the Creative Commons Attribution License, which permits unrestricted use, distribution, and reproduction in any medium, provided the original work is properly cited.

\begin{abstract}
The new Schiff base ligand (FIAS) 2,4-furyliminobenzylacetophenone has been synthesized with 4-aminoacetophenone and furane-2-carboxaldehyde by condensation in ethanol. Metal complexes of the ligand were prepared with chloride salts of copper(II), nickel(II) and cobalt(II) in ethanol. The ligand and its metal complexes have been characterized by microanalysis, magnetic susceptibility, FTIR, ${ }^{1} \mathrm{H}$ and ${ }^{13} \mathrm{C}$ NMR, mass spectrum, and UV-visible spectroscopy techniques. From these findings, it is suggested that metal ion coordinate by imines nitrogen and carboxylic oxygen atoms of FIAS to form octahedral geometry. All the newly compounds were tested antimicrobial activity against bacterial and fungal species.
\end{abstract}

\section{Introduction}

The chemistry of transition metal complexes with multidentate [1-6] ligands have been attracted particular attention because these metal ions can exhibit several oxidation states. The different oxidation states of these complexes showed a strong role in bioinorganic chemistry and redox enzyme system. This may provide the basis of models for active sites of biological systems or act as catalysts. Although numerous transition metal complexes [7-10] of Schiff bases have structurally characterized relatively few free Schiff bases have been similarly characterized. A combination of distinctly different metal ions bind with one ligand can lead to materials with interesting new properties [11-15] for example, specific sensors, molecular wire, magnetic and optical devices. The flexibility of Schiff base ligands can be improved by hydrogenation of their $\mathrm{C}=\mathrm{N}$ bonds; they should thus coordinate metal ions move easily. For these reasons, reduced Schiff base have recently gained considerable attention. Schiff bases of 4-aminoantipyrine and its complexes are known for their variety of applications [16-22] in the areas of catalysis, clinical applications and pharmacologically. Antipyrine and its derivatives [23-30] show antibacterial and antitumor activities. Our research was ongoing to establish the fact that nonbiologically active compounds become biologically active, and less biologically active become more upon coordination/chelation with metal ions. In this paper, we synthesized the Schiff base and their metal complexes were characterized by their IR, NMR, molar conductance, and magnetic moments electronic elemental analysis mass spectrum and UV-Visible spectroscopy. Schiff base ligands and their metal complexes were screened for their antimicrobacterial activity against Staphylococcus aureus (ATCC 25923), Staphylococcus aureus (ATCC 3160) bacterial species and Cabdida albicans (227), and Staphylococcus cereviscae (361) fungal species. The Schiff base showed varied antibacterial and antifungal activity against one or more strains, respectively, and their activity was enhanced on coordination or chelation.

\section{Experimental}

2.1. Material and Methods. Solvents and metals salts were used analytical grade. IR spectra used were analytical grade. 


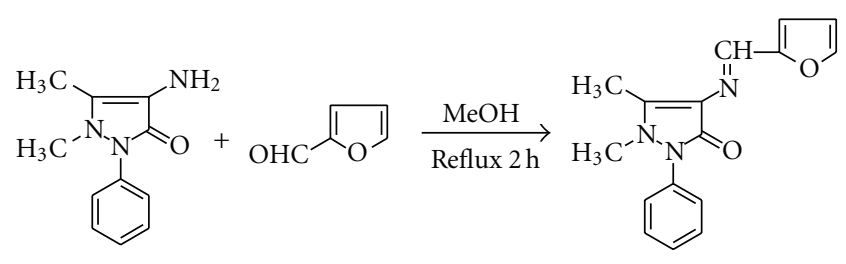

Scheme 1: Route for the synthesis of the 2-furanecarboxaldehydeacetophenone.

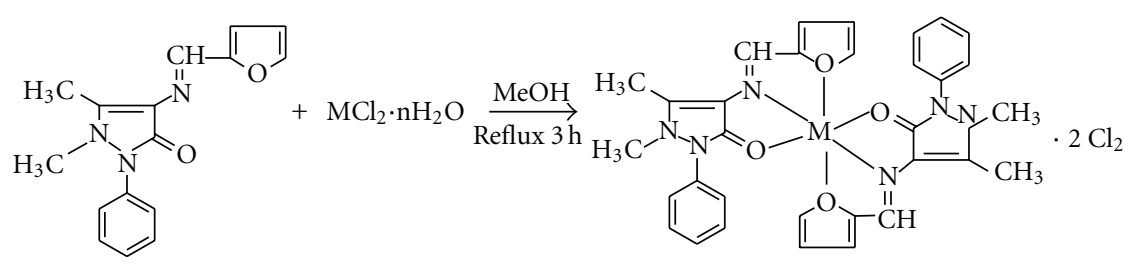

Scheme 2: Route for the synthesis of the Metal complexes.

IR spectra were recorded on Shimadzu-160 Spectrometer using $\mathrm{KBr}$ discs in the range $4000-400 \mathrm{~cm}^{-1}$. NMR spectra were recorded on a Bruker DPX-400 Spectrometer using DMSO- $\mathrm{d}_{6}$ solvent and TMS as the internal reference at room temperature. UV-visible spectra were obtained in DMSO/DMF. CHN analyses were performed using a CarloErba 1106 Elemental Analyzer; conductance and magnetic measurements were carried out on solid compounds using the respective instruments. Antimicrobial activities were done at ACBR, Delhi University, India.

2.2. Synthesis of Ligand. In a round bottom flask, furan-2carboxaldehyde $(0.01 \mathrm{mmol}, 0.35 \mathrm{~mL})$ in methanol $(15 \mathrm{~mL})$ and 4-aminoantipyrine $(0.1 \mathrm{mmol}, 0.203 \mathrm{~g})$ in methanol $(15 \mathrm{~mL})$ were stirred by a magnetic stirrer for about 30 minutes. The mixture was refluxed for $2 \mathrm{~h}$ on the heating mental at $50^{\circ} \mathrm{C}$. After completion of the reaction monitored through TLC, it was cooled at room temperature to afford a yellow solid product which was filtered, washed with cold methanol then with ether and dried (Scheme 1).

Yield. 52\%; M.P. $240^{\circ} \mathrm{C}$, Mol. wt. 281, color: yellow; analytical data for $\mathrm{C}_{16} \mathrm{H}_{15} \mathrm{~N}_{3} \mathrm{O}_{2}$ found (calc.): $\mathrm{C}, 62.32$ (61.99); $\mathrm{H}, 5.33$ (4.91); N, 14.94 (13.97). IR $\left(\mathrm{KBr} / \mathrm{cm}^{-1}\right) 1637 v_{\mathrm{CH}=\mathrm{N}}$, $1690 v_{\mathrm{C}=\mathrm{O}}, 1530 v_{\mathrm{C}-\mathrm{O}}, 1298 v_{\mathrm{N}-\mathrm{N}}$. ESI-MS, m/z Data found (calc.): 321 (320), ${ }^{1} \mathrm{H}$ NMR (DMSO-d 6 ) $\delta$ ppm: 1.601 (s, $\left.3 \mathrm{H}, \mathrm{H}_{3} \mathrm{C}-\mathrm{C}\right), 1.714\left(\mathrm{~s}, 3 \mathrm{H}, \mathrm{H}_{3} \mathrm{C}-\mathrm{N}\right), 7.158-7.953(\mathrm{~m}, 9 \mathrm{H}$, $\mathrm{Ar}), 3.18\left(\mathrm{~s}, 3 \mathrm{H}, \mathrm{H}_{3} \mathrm{C}-\mathrm{O}\right), 8.92(\mathrm{~s}, 1 \mathrm{H}, \mathrm{CH}=\mathrm{N}) .{ }^{13} \mathrm{C}$ NMR $\left(\right.$ DMSO-d $\left.{ }_{6}\right) \delta$ ppm: $10.07\left(1 \mathrm{C}, \mathrm{CH}_{3}-\mathrm{C}\right), 18.97\left(1 \mathrm{C}, \mathrm{CH}_{3}-\mathrm{N}\right)$, 56.33 (1C, $\mathrm{CH}_{3}-\mathrm{O}$ ), 117.53-121.07 (12C, $\mathrm{CH}-\mathrm{Ar}$.), 143.23 $(1 \mathrm{C}, \mathrm{C}-\mathrm{N}), 153.88(1 \mathrm{C}, \mathrm{C}=\mathrm{O}), 164.95(1 \mathrm{C}, \mathrm{CH}=\mathrm{N})$.

2.3. Synthesis of Metal Complexes. For the synthesis of metal complexes, a solution of 2-furanecarboxaldehyde-4iminoacetophenone ligand $(0.1 \mathrm{mmol}, 0.317 \mathrm{~g})$ in methanol $(50 \mathrm{~mL})$ was added to a magnetically stirred solution of $\mathrm{MCl}_{2} \cdot \mathrm{nH}_{2} \mathrm{O}(0.1 \mathrm{mmol})$ in methanol $(30 \mathrm{~mL})$ at a required equimolor ratio of $\mathrm{M}: \mathrm{L}(1: 2)$. The mixture was refluxed for $3 \mathrm{~h}$ and then cooled to room temperature. On cooling, a colored solid product was formed. The solid was filleted, washed with methanol, then ether and dried. Crystallization from methanol gave the desired metal complexes (Scheme 2).

\subsection{1. $\left[\mathrm{Ni}\left(\mathrm{L}_{2}\right) \mathrm{Cl}_{2}\right]$ Complex}

Yield. 38\%; M.P.: 320; Mol. wt. 869; color: dark green; analytical data for $\left[\mathrm{NiC}_{32} \mathrm{H}_{30} \mathrm{~N}_{6} \mathrm{O}_{4} \mathrm{Cl}_{2}\right]$ found (calc.): $\mathrm{C}$, 44.18 (44.01), H, 3.45 (3.22), N, 9.66 (9.35). IR $\left(\mathrm{KBr} / \mathrm{cm}^{-1}\right)$ : $1598 v_{\mathrm{CH}=\mathrm{N}}, 1650 \nu_{\mathrm{C}=\mathrm{O}}, 512 \nu_{\mathrm{M}-\mathrm{N}}, 453 \nu_{\mathrm{M}-\mathrm{O}}, 390 \nu_{\mathrm{M}-\mathrm{Cl}}{ }^{1} \mathrm{H}$ NMR (DMSO- $\left.\mathrm{d}_{6}\right) \delta$ ppm: 1.601 (s, 3H, $\left.\mathrm{H}_{3} \mathrm{C}-\mathrm{C}\right), 1.714$ (s, $3 \mathrm{H}, \mathrm{H}_{3} \mathrm{C}-\mathrm{N}$ ), 7.158-7.953 (m, 9H, Ar), 3.18 (s, 3H, H ${ }_{3} \mathrm{C}-$ $\mathrm{O}), 8.12(\mathrm{~s}, 1 \mathrm{H}, \mathrm{CH}=\mathrm{N}) .{ }^{13} \mathrm{C}$ NMR $\left(\mathrm{DMSO}_{6} \mathrm{~d}_{6}\right) \delta \mathrm{ppm}$ : $10.07\left(1 \mathrm{C}, \mathrm{CH}_{3}-\mathrm{C}\right), 18.97\left(1 \mathrm{C}, \mathrm{CH}_{3}-\mathrm{N}\right), 56.33\left(1 \mathrm{C}, \mathrm{CH}_{3}-\right.$ O), 117.53-121.07 (12C, CH-Ar.), 143.23 (1C, C-N), 153.12 (1C, $\mathrm{C}=\mathrm{O}), 164.25(1 \mathrm{C}, \mathrm{CH}=\mathrm{N})$. UV-vis $(\mathrm{DMSO}): \lambda_{\max }$ $\left(\mathrm{cm}^{-1}\right), 16,670,27,780$. B.M. $\left(\mu_{\text {eff }}\right): 2.5$. Molar conductance $\left(\Omega^{-1} \mathrm{~cm}^{2} \mathrm{~mol}^{-1}\right): 16.45$.

\subsection{2. $\left[\mathrm{Cu}\left(\mathrm{L}_{2}\right) \mathrm{Cl}\right] \mathrm{Cl}$ Complex}

Yield. 32\%; M.P.: $345^{\circ} \mathrm{C}$, Mol. wt. 802; color: light green; analytical data for $\left[\mathrm{CuC}_{32} \mathrm{H}_{30} \mathrm{~N}_{6} \mathrm{O}_{4} \mathrm{Cl}\right] \mathrm{Cl}_{2}$ found (calc.): C, 47.88 (46.85); H, 3.74 (3.01); N, 10.47 (10.17). IR $\left(\mathrm{KBr} / \mathrm{cm}^{-1}\right): 1602 v_{\mathrm{CH}=\mathrm{N}}, 1678 v_{\mathrm{C}=\mathrm{O}}, 1530 v_{\mathrm{C}-\mathrm{O}}, 1296 v_{\mathrm{N}-\mathrm{N}}$, $544 v_{\mathrm{M}-\mathrm{N}}, 447 v_{\mathrm{M}-\mathrm{O}}, 398 \nu_{\mathrm{M}-\mathrm{Cl} .}{ }^{1} \mathrm{H}$ NMR (DMSO-d 6 ) $\delta \mathrm{ppm:}$ 1.601 (s, 3H, $\mathrm{H}_{3} \mathrm{C}-\mathrm{C}$ ), 1.714 (s, 3H, $\mathrm{H}_{3} \mathrm{C}-\mathrm{N}$ ), 7.158-7.953 (m, 9H, Ar), $3.18\left(\mathrm{~s}, 3 \mathrm{H}, \mathrm{H}_{3} \mathrm{C}-\mathrm{O}\right), 8.13(\mathrm{~s}, 1 \mathrm{H}, \mathrm{CH}=\mathrm{N}) .{ }^{13} \mathrm{C}$ NMR (DMSO-d $\left.{ }_{6}\right) \delta$ ppm: $10.07\left(1 \mathrm{C}, \mathrm{CH}_{3}-\mathrm{C}\right), 18.97$ (1C, $\left.\mathrm{CH}_{3}-\mathrm{N}\right), 56.33$ (1C, $\left.\mathrm{CH}_{3}-\mathrm{O}\right), 117.53-121.07$ (12C, $\mathrm{CH}-\mathrm{Ar}$.), $143.23(1 \mathrm{C}, \mathrm{C}-\mathrm{N}), 153.10(1 \mathrm{C}, \mathrm{C}=\mathrm{O}), 164.05(1 \mathrm{C}, \mathrm{CH}=\mathrm{N})$. UV-vis (DMSO): $\lambda_{\max }\left(\mathrm{cm}^{-1}\right), 14,920,16,390,27,250$. B.M. $\left(\mu_{\text {eff }}\right): 3.5$. Molar conductance $\left(\Omega^{-1} \mathrm{~cm}^{2} \mathrm{~mol}^{-1}\right): 16.45$.

\subsection{3. $\left[\mathrm{Co}\left(\mathrm{L}_{2}\right) \mathrm{Cl}\right] \mathrm{Cl}$ Complex}

Yield. 30\%; M.P.: 320; Mol. wt. 870; color: dark green; analytical data for [Co $\left.\mathrm{C}_{32} \mathrm{H}_{30} \mathrm{~N}_{6} \mathrm{O}_{4} \mathrm{Cl}\right] \mathrm{Cl}_{2}$ found (calc.): $\mathrm{C}$, 44.13 (43.45), H, 3.44 (3.01), N, 9.65 (9.25). IR $\left(\mathrm{KBr} / \mathrm{cm}^{-1}\right)$ : 
TABLE 1: Antibacterial screening data of metal complexes of 2-furanecarboxaldehyde-4-iminoacetophenone Schiff base.

\begin{tabular}{lcccc}
\hline Compound & \multicolumn{3}{c}{$\begin{array}{c}\text { Average \% inhibition after 48 h. (conc. in ppm) } \\
\text { Staphylococcus aureus } \\
\text { (ATCC 25923) }\end{array}$} \\
\hline FIAS & 500 & 1000 & 500 & 1000 \\
{$\left[\mathrm{Co}\left(\mathrm{L}_{2}\right)\right] \mathrm{Cl}_{2}$} & 30 & 42 & 31 & 35 \\
{$\left[\mathrm{Ni}\left(\mathrm{L}_{2}\right)\right] \mathrm{Cl}_{2}$} & 44 & 51 & 42 & 53 \\
{$\left[\mathrm{Cu}\left(\mathrm{L}_{2}\right)\right] \mathrm{Cl}_{2}$} & 44 & 50 & 42 & 54 \\
Bavistin & 43 & 51 & 43 & 99 \\
\hline
\end{tabular}

TABLE 2: Fungicidal screening data of metal complexes of 2-furanecarboxaldehyde-4-iminoacetophenone Schiff base.

\begin{tabular}{|c|c|c|c|c|}
\hline \multirow{3}{*}{ Compound } & \multicolumn{4}{|c|}{ Average $\%$ inhibition after 48 h. (conc. in ppm) } \\
\hline & \multicolumn{2}{|c|}{$\begin{array}{l}\text { Cabdida albicans } \\
\text { (ATCC 227) }\end{array}$} & \multicolumn{2}{|c|}{$\begin{array}{c}\text { Staphylococcus cereviscae } \\
(\text { ATCC 361) }\end{array}$} \\
\hline & 500 & 1000 & 500 & 1000 \\
\hline FIAS & 5 & 8 & 5 & 10 \\
\hline$\left[\mathrm{Co}\left(\mathrm{L}_{2}\right)\right] \mathrm{Cl}_{2}$ & 8 & 14 & 7 & 15 \\
\hline$\left[\mathrm{Ni}\left(\mathrm{L}_{2}\right)\right] \mathrm{Cl}_{2}$ & 9 & 11 & 8 & 16 \\
\hline$\left[\mathrm{Cu}\left(\mathrm{L}_{2}\right)\right] \mathrm{Cl}_{2}$ & 9 & 17 & 9 & 12 \\
\hline Streptomycin & 16 & 18 & 16 & 18 \\
\hline
\end{tabular}

$1602 v_{\mathrm{CH}=\mathrm{N}}, 1648 v_{\mathrm{C}=\mathrm{O}}, 567 v_{\mathrm{M}-\mathrm{N}}, 450 v_{\mathrm{M}-\mathrm{O}}, 390 \nu_{\mathrm{M}-\mathrm{Cl}} .{ }^{1} \mathrm{H}$ NMR (DMSO-d $\left.{ }_{6}\right) \delta$ ppm: $1.465\left(\mathrm{H}_{3} \mathrm{C}-\mathrm{C}\right), 1.714\left(\mathrm{H}_{3} \mathrm{C}-\mathrm{N}\right)$, 7.158-7.953 (CH-Ar), $3.18\left(\mathrm{H}_{3} \mathrm{C}-\mathrm{O}\right), 8.12(\mathrm{CH}=\mathrm{N}) .{ }^{13} \mathrm{C}$ NMR (DMSO-d $\left.{ }_{6}\right) \delta$ ppm: $10.07\left(\mathrm{CH}_{3}-\mathrm{C}\right), 18.97\left(\mathrm{CH}_{3}-\right.$ $\mathrm{N}), 56.33\left(\mathrm{CH}_{3}-\mathrm{O}\right), 117.53-121.07$ ( $\left.\mathrm{CH}-\mathrm{Ar}.\right), 143.23(\mathrm{C}-$ $\mathrm{N}), 153.12(\mathrm{C}=\mathrm{O}), 164.25(\mathrm{CH}=\mathrm{N})$. UV-vis $(\mathrm{DMSO}): \lambda_{\max }$ $\left(\mathrm{cm}^{-1}\right), 15000,16390$ and 27250 . B.M. $\left(\mu_{\mathrm{eff}}\right): 1.55$. Molar conductance $\left(\Omega_{\mathrm{M}}^{-1} \mathrm{~cm}^{2} \mathrm{~mol}^{-1}\right): 11.1$.

\section{Biological Activity}

3.1. Antibacterial Activity. The newly synthesized metal complexes were screened in vitro for their antibacterial activity against Staphylococcus aureus (ATCC 25923), and Staphylococcus aureus (ATCC 3160) bacterial species using the agar well diffusion method. 12-24 h bacterial solution containing $\sim 10^{4}-10^{6}$ colony forming units (CFU)/mL were used. The test sample's $(1 \mathrm{mg} / \mathrm{mL}$ in DMF) concentration $(100 \mu \mathrm{L})$ was introduced in the petric disc. New petric dishes were incubated immediately at $37^{\circ} \mathrm{C}$ for $24 \mathrm{~h}$ activities was determine by measuring the diameter of zones showing complete inhibition ( $\mathrm{mm})$. Growth inhibition was compared with the standard drug (Table 1).

3.2. Antifungal Activity. Antifungal activities of all compounds were studies against two fungal cultures Cabdida albicans (227) and Staphylococcus cereviscae (361) fungal species. Sabouraud dextrose agar was seeded with $10^{5} \mathrm{~mL}^{-1}$ fungal spare suspension and transferred to petric plates. Dishes soaked in $20 \mathrm{~mL}(10 \mu \mathrm{g} / \mathrm{mL}$ in DMF) of the entire agar surface. The plates were incubated at $32^{\circ} \mathrm{C}$ for $24 \mathrm{~h}$. the results were recorded as zones of inhibition $(\mathrm{mm})$ and compared with the standard drug Streptomycin (Table 2).

3.3. Minimum Inhibitory Concentration. Compounds showing antibacterial activity over $8 \%$ were selected for minimum inhibitory concentration studies. The MIC was determined using the disc diffusion technique by prepared uses containing 500 and $1000 \mu \mathrm{g} / \mathrm{mL}$ of the compounds (Figure 1).

\section{Result and Discussion}

The structure of newly synthesized ligand was established with the help of their IR, NMR $\left({ }^{1} \mathrm{H} \&{ }^{13} \mathrm{C}\right)$, mass spectrum and microanalytical data. All the metal complexes and Schiff base ligand were stable in air and moisture and they were synthesized by the stoichiometric reaction of the corresponding metal (II) chloride with ligand in a molar ratio $\mathrm{M}: \mathrm{L}$ of $1: 2$. All of the metal complexes were insoluble in the common organic solvents and only soluble in DMF/DMSO. Molar conductance value of the soluble complexes in DMF $\left(10^{-3} \mathrm{M}\right.$ solution at $\left.25^{\circ} \mathrm{C}\right)$ indicated that chloride ion were in the outer sphere and show the non-electrolytic in nature but in the $\mathrm{Ni}$ (II) complex, chloride ions coordinated in the inner sphere and it was nonelectrolytic in nature. We agree with the proposed structure of the ligand on the basis of elemental analysis data in which the ligand contain two donor sitesone is azomethine $(\mathrm{HC}=\mathrm{N})$ nitrogen and other carbonyl $(\mathrm{C}=\mathrm{O})$ oxygen atom. IR spectra of the ligand observed at $1615 \mathrm{~cm}^{-1}$ are assigned to the $\nu(\mathrm{C}=\mathrm{N})$ mode and a band at $810 \mathrm{~cm}^{-1}$ due to $\nu(\mathrm{C}-\mathrm{N})$ pyrrolyl ring. The peak of azomethine group was found in the lower wave frequency in the IR spectra of the complexes which was evidence of the nitrogen 


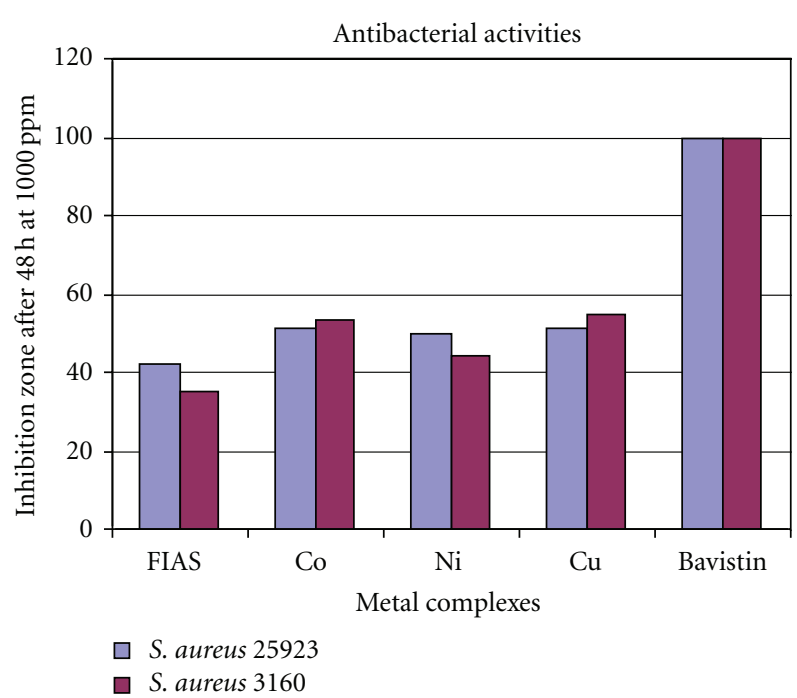

(a)

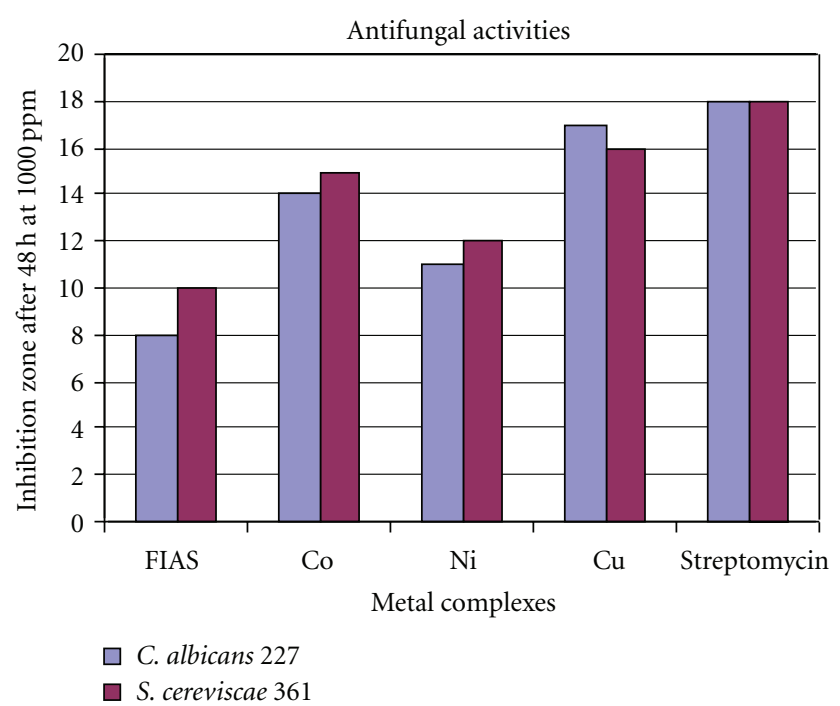

(b)

Figure 1: Plot of antibacterial (a) and antifungal (b) activity of ligand and their metal complexes in 1000 ppm conc.

bonding of the azomethine group to the central metal ions. The $v(\mathrm{C}=\mathrm{O})$ carbonyl band in the ligand appeared at $1645 \mathrm{~cm}^{-1}$. This frequency was shifted to the lower frequency in the spectra of the complexes which was indicated the coordination of the carbonyl oxygen atom to the central metal ions. This is further confirmed by the appearance of the new band at 515-525 and $425-430 \mathrm{~cm}^{-1}$ due to the $\nu(\mathrm{M}-\mathrm{N})$ and $v(\mathrm{M}-\mathrm{O})[35,36]$. The NMR spectrum of the ligand was done in DMSO- $\mathrm{d}_{6}$. The ${ }^{1} \mathrm{H}$ NMR spectral data are reported along with the possible assignments in the experimental section. All the protons due to aromatic groups were found to be in their expected region. The conclusions of these studies lend further support to the mode of bonding discussed in their IR spectra. ${ }^{13} \mathrm{C}$ NMR spectrum of the ligand, signals between 111.9 and 181.5 due to aromatic ring carbons. The peak of carbonyl carbon at $169.7 \mathrm{ppm}$ was shifted to the lower frequencies. The mass spectrum of the ligand shows a peak at 321.22. This suggests that the ligand exists in a dimeric form probably through $\mathrm{H}$-bonding. The presence of fragments values 121, 23, 67 and 320 show that the fragmentation has taken place at $-\mathrm{C}=\mathrm{N}-$. The mass spectrum clearly suggests existence of ligand in the hydrazones form. The UV-visible spectrum of copper(II) complex in DMSO solution displays a broad band at $10718 \mathrm{~cm}^{-1}$ and a welldefined shoulder around $22831 \mathrm{~cm}^{-1}$ attributable to ${ }^{2} \mathrm{~B}_{1 \mathrm{~g}} \rightarrow$ ${ }^{2} \mathrm{~A}_{1 \mathrm{~g}}$ transitions which strongly favour octahedral geometry around the $\mathrm{Cu}(\mathrm{II})$ ion [34]. This is further supported by the magnetic susceptibility value (1.83 $\mathrm{BM})$. The cobalt complex shows a d-d band at $16216 \mathrm{~cm}^{-1}$ as signed to ${ }^{2} \mathrm{~A}_{\mathrm{lg}} \rightarrow$ ${ }^{2} \mathrm{~B}_{1 \mathrm{~g}}$ transition which confirmed square-planner geometry. This is further confirmed by its magnetic susceptibility value (3.85 BM). The electronic spectra of the nickel(II) complex exhibited [31-33] absorption bands at $\sim 16,670$ and $\sim 27,780 \mathrm{~cm}^{-1}$, attributable to ${ }^{3} \mathrm{~A}_{2 \mathrm{~g}} \rightarrow{ }^{3} \mathrm{~T}_{1 \mathrm{~g}}(\mathrm{~F})$ and ${ }^{3} \mathrm{~A}_{2 \mathrm{~g}} \rightarrow$ ${ }^{3} \mathrm{~T}_{\mathrm{lg}}(\mathrm{P})$, transitions, respectively, in an octahedral geometry. The calculated values of the ligand field parameters lie in the range reported for an octahedral structure [35, 36]. Also, the values of the magnetic moment (3.2-3.7 B.M.) may be taken as additional evidence for their octahedral structure. The magnetic moment values are of great significance in a structural context in the case of $\mathrm{Co}$ (II) complexes. Magnetic moments of tetrahedral, octahedral and square planar complexes differ significantly and therefore structural type can be easily identified using magnetic data. In octahedral complexes, the ground state $\left({ }^{4} \mathrm{~T}_{\mathrm{lg}}\right)$ is orbitally degenerate and this causes large orbital contribution to the magnetic moment. The $\mu_{\text {eff }}$ value measured for the Co(II) complex is 5.32 B.M, indicating octahedral geometry [37] of the $\mathrm{Co}(\mathrm{II})$ ion in the complex. The reflectance spectrum of the complex showed a band at $656 \mathrm{~nm}$ and a shoulder at $477 \mathrm{~nm}$, besides the ligand absorptions. The former band would be due to ${ }^{4} \mathrm{~T}_{1 \mathrm{~g}} \rightarrow{ }^{4} \mathrm{~A}_{2 \mathrm{~g}}$ electronic transition, indicating an octahedral configuration around $\mathrm{Co}$ (II) ions. On the basis of the above observations, it is tentatively suggested that all of the complexes show an octahedral geometry in which ligands act as bidentates. These possibly accommodate themselves around the metal atom in such a way that a stable chelate ring is formed giving, in turn, stability to the formed metal complexes.

\section{Conclusions}

In this paper we have described that the all the synthesized transition metal complexes of Schiff base by condensation method. In the present investigations, all the complexes found to be mononuclear were obtained for $\mathrm{Cu}$ (II), $\mathrm{Ni}$ (II) and $\mathrm{Co}(\mathrm{II})$, cations in presence of ligand. The results of antimicrobial activities show that the metal-complexes exhibit antimicrobial properties and it is important to note that they show enhanced inhibitory activity compared to parent ligand. All the investigated compounds showed less to good activity against $S$. aureus. 


\section{Acknowledgments}

The authors are thankful to SAIF, CDRI, Lucknow, and ACBR, New Delhi, India, for providing the spectral, analytical facilities and biological activity, respectively.

\section{References}

[1] S. S. Sivakumar and M. R. P. Kurup, "Structural studies of six and four coordinate zinc(II), nickel(II) and dioxovanadium(V) complexes with thiosemicarbazones," Journal of Molecular Structure, vol. 655, no. 1, pp. 47-58, 2003.

[2] P. Bindu, M. R. P. Kurup, and T. R. Satyakeerthy, "Epr, cyclic voltammetric and biological activities of copper(II) complexes of salicylaldehyde N(4)-substituted thiosemicarbazone and heterocyclic bases," Polyhedron, vol. 18, no. 3-4, pp. 321-331, 1999.

[3] R. P. John, A. Sreekanth, M. R. P. Kurup, A. Usman, A. R. Ibrahim, and H. K. Fun, "Spectral studies and structure of a 2-hydroxyacetophenone 3-hexamethyleneiminyl thiosemicarbazonate(-2) copper(II) complex containing 1,10phenanthroline," Spectrochimica Acta A, vol. 59, no. 6, pp. 1349-1358, 2003.

[4] Y. F. Yuan, J. T. Wang, M. C. Gimeno, A. Laguna, and P. G. Jones, "Synthesis and characterisation of copper complexes with $N$-ferrocenoyl- $N^{\prime}$-aryl(alkyl)thioureas," Inorganica Chimica Acta, vol. 324, no. 1-2, pp. 309-317, 2001.

[5] C. K. Alphonsa and M. R. P. Kurup, "Synthesis and characterization of nickel(II) compixxes of zacetylpyridine thiosemicarbm, one," Synthesis and Reactivity in Inorganic and MetalOrganic Chemistry, vol. 29, no. 5, pp. 805-815, 1999.

[6] A. Sreekanth, U. L. Kala, C. R. Nayar, and M. R. P. Kurup, "Cobalt(III) complexes of 2-hydroxyacetophenone N(4)phenyl semicarbazone containing heterocyclic coligands: syntheses, structure and spectral studies," Polyhedron, vol. 23, no. 1, pp. 41-47, 2004.

[7] K. Saberyan, E. Zolfonoun, M. Shamsipur, and M. SalavatiNiasari, "Amberlite XAD-4 impregnated with a new pentadentate Schiff base: a chelating collector for separation and preconcentration of trace amounts of gallium (III) and indium (III)," Acta Chimica Slovenica, vol. 57, no. 1, pp. 222229, 2010.

[8] A. R. Paital, D. Mandal, X. Huang, G. Aromi, and D. Ray, "Structure and dimensionality of coordination complexes correlated to piperazine conformation: from discrete [ $\left.\mathrm{Cu}_{2}^{\mathrm{II}}\right]$ and $\left[\mathrm{Cu}_{4}^{\mathrm{II}}\right]$ complexes to a $\mu_{1,3}-\mathrm{N}_{3}^{-}$bridged $\left[\mathrm{Cu}_{2}^{\mathrm{II}}\right]_{n}$ chain," Dalton Transactions, vol. 23, no. 8, pp. 1352-1362, 2009.

[9] J. G. Małecki, "Synthesis, crystal, molecular and electronic structures of ruthenium complexes with a benzoxazole derivative ligand," Polyhedron, vol. 31, pp. 159-166, 2012.

[10] I. Demir, M. Bayrakci, K. Mutlu, and A. I. Pekacar, "Synthesis and characterization of a novel iminooxime schiff base ligand and its complexation with copper(II), nickel(II), zinc(II), cadmium(II), and cobalt(II)," Acta Chimica Slovenica, vol. 55, no. 1, pp. 120-124, 2008.

[11] M. Kwiathowski and G. Bandoli, "Nickel(II) complexes with unsymmetrical quadridentate Schiff bases having a pendant $N$-acyl substituent," Journal of the Chemical Society Dalton Transactions, no. 3, pp. 379-384, 1992.

[12] Z. X. Lei, Q. Y. Zhu, X. Zang, W. Luo, W. Q. Mu, and J. Dai, "Indium-sulfur supertetrahedral clusters integrated with a metal complex of 1,10-phenanthroline," Inorganic Chemistry, vol. 49, no. 10 , pp. 4385-4387, 2010.
[13] D. L. Grisenti, M. B. Smith, L. Fang, N. Bishop, and P. S. Wagenknecht, "A convenient synthesis of isocyclam and ane $\mathrm{N}_{4}$ and the photophysics of their dicyanochromium(III) complexes," Inorganica Chimica Acta, vol. 363, no. 1, pp. 157$162,2010$.

[14] C. Kriza and T. Parrnau, "Complexes of tin (IV) with some bidentate Schiff bases derived from 1-H-indol-2,3-dione," Acta Chimica Slovenica, vol. 48, no. 3, pp. 445-452, 2001.

[15] V. Aanandhi, S. George, and V. Vaidhyalingam, "Synthesis and antimicrobial activities of 1-(5-substituted-2-oxo indolin3-ylidene)-4-(substituted pyridin-2-yl)thiosemicarbazide," Arkivoc, vol. 2008, no. 11, pp. 187-194, 2008.

[16] Z. H. Chohan, A. Munawar, and C. T. Supuran, "Transition metal ion complexes of Schiff-bases. Synthesis, characterization and antibacterial properties," Metal-Based Drugs, vol. 8, no. 3, pp. 137-143, 2001.

[17] E. A. Liberta and D. X. West, "A convenient synthesis of isocyclam and [16] $\mathrm{aneN}_{4}$ and the photophysics of their dicyanochromium(III) complexes," Inorganica Chimica Acta, vol. 363, no. 1, pp. 157-162, 2010.

[18] D. Kovala-Demertzi, A. Domopoulou, M. Demertzis, C. P. Raptopoulou, and A. Terzis, "Coordinating properties of 2-acetylpyridine thiosemicarbazone. Palladium(II) complexes with neutral and deprotonated ligand. X-ray structure of bromo(2-acetylpyridine thiosemicarbazonato) palladium(II)," Polyhedron, vol. 13, no. 12, pp. 1917-1925, 1994.

[19] D. X. West, H. Gebremedhin, R. J. Butcher, and J. P. Jasinski, "Molecular structure and spectral properties of bromo(2acetylpyridine $\left.{ }^{4} N\right)$ copper(II)," Transition Metal Chemistry, vol. 20, no. 1, pp. 84-87, 1995.

[20] M. A. Jasim and A. Karawi, "Synthesis and characterization of a new $\mathrm{N}_{2} \mathrm{~S}_{2}$ Schiff base ligand and its complexes with nickel(II), copper(II) and cadmium(II) including the kinetics of complex formation," Transition Metal Chemistry, vol. 34, no. 8, pp. 891-897, 2009.

[21] J. K. Clegg, D. J. Bray, K. Gloe et al., "Synthetic, structural, electrochemical and solvent extraction studies of neutral trinuclear $\mathrm{Co}(\mathrm{ii}), \mathrm{Ni}(\mathrm{ii}), \mathrm{Cu}(\mathrm{ii})$ and $\mathrm{Zn}$ (ii) metallocycles and tetrahedral tetranuclear Fe(iii) species incorporating 1,4-aryllinked bis- $\beta$-diketonato ligands," Dalton Transactions, no. 10, pp. 1331-1340, 2008.

[22] Z. F. Dawood, T. J. Mohammed, and M. R. Sharif Iraqi, "New nickel (II) complexes with benzilbis (semicarbazone) and dithiocarbamate ligands," Journal of Veterinary Science, no. 23, supplement 2, pp. 135-141, 2009.

[23] E. Champeil, M. M. Paz, S. Ladwa, C. C. Clement, A. Zatorski, and M. Tomasz, "Synthesis of an oligodeoxyribonucleotide adduct of mitomycin $\mathrm{C}$ by the postoligomerization method via a triamino mitosene," Journal of the American Chemical Society, vol. 130, no. 29, pp. 9556-9565, 2008.

[24] V. Philip, V. Suni, M. R. Prathapachandra Kurup, and M. Nethaji, "Structural and spectral studies of nickel(II) complexes of di-2-pyridyl ketone N4,N4-(butane-1,4-diyl) thiosemicarbazone," Polyhedron, vol. 23, no. 7, pp. 1225-1233, 2004.

[25] P. Bindu, M. R. P. Kurup, and T. R. Satyakeerthy, "Epr, cyclic voltammetric and biological activities of copper(II) complexes of salicylaldehyde $\mathrm{N}(4)$-substituted thiosemicarbazone and heterocyclic bases," Polyhedron, vol. 18, no. 3-4, pp. 321-331, 1999.

[26] S. Arayne, N. Sultana, U. Haroon, and M. A. Mesaik, "Synthesis, characterization, antibacterial and anti-inflammatory 
activities of enoxacin metal complexes," Bioinorganic Chemistry and Applications, vol. 2009, Article ID 914105, 6 pages, 2009.

[27] H. Torayama, T. Nishide, H. Asada, M. Fujiwara, and T. Matsushita, "Preparation and characterization of novel cyclic tetranuclear manganese (III) complexes: $\mathrm{Mn}^{\mathrm{III}}{ }_{4}$ (X-salmphen $)_{6} \quad\left(\mathrm{X}\right.$-salmphen $\mathrm{H}_{2}=\mathrm{N}, \mathrm{N}$-di-substituted-salicylidene1,3-diaminobenzene $(\mathrm{X}=\mathrm{H}, 5-\mathrm{Br})$ )," Polyhedron, vol. 16, no. 21, pp. 3787-3794, 1997.

[28] E. M. Hodnett and W. J. Dunn, "Cobalt derivatives of Schiff bases of aliphatic amines as antitumor agents," Journal of Medicinal Chemistry, vol. 15, no. 3, p. 339, 1972.

[29] K. Singh, Y. Kumar, P. Puri, M. Kumar, and C. Sharma, "Cobalt, nickel, copper and zinc complexes with 1,3-diphenyl1H-pyrazole-4-carboxaldehyde Schiff bases: Antimicrobial, spectroscopic, thermal and fluorescence studies," European Journal Medicinal Chemistry, vol. 52, pp. 313-321, 2012.

[30] V. M. Downey, B. R. Que, and A. G. So, "Degradation of DNA by 1,-10-phenanthroline," Biochemical and Biophysical Research Communications, vol. 93, no. 1, pp. 264-270, 1980.

[31] E. L. Marshall, D. R. Graham, and K. A. Reith, "Cleavage of deoxyribonucleic acid by the 1,10-phenanthroline-cuprous complex. Hydrogen peroxide requirement and primary and secondary structure specificity," Biochemistry, vol. 20, no. 2, pp. 224-250, 1981.

[32] S. Djebbar-Sid, B. O. Benali, and J. P. Deloume, "Synthesis, characterization, electrochemical behaviour and catalytic activity of manganese(II) complexes with linear and tripodal tetradentate ligands derived from Schiff bases," Transition Metal Chemistry, vol. 23, no. 4, pp. 443-447, 1998.

[33] D. Kovala-Demertzi, P. N. Yadav, M. A. Demertzis, and M. Coluccia, "Synthesis, crystal structure, spectral properties and cytotoxic activity of platinum(II) complexes of 2-acetyl pyridine and pyridine-2-carbaldehyde N(4)-ethylthiosemicarbazones," Journal of Inorganic Biochemistry, vol. 78, no. 4, pp. 347-354, 2000.

[34] A. G. Bingham, H. Boegge, A. Mueller, E. W. Ainscough, and A. M. Brodie, "Formation of germanium-nitrogen double bonds in reactions of the electron-rich germylene bis[bis(trimethylsilyl)amido]germanium(II) with a range of diazo-compounds," Journal of the Chemical Society Dalton Transactions, vol. 493, no. 3, pp. 501-508, 1987.

[35] S. Padhye and G. F. Kauffman, "Transition metal complexes of semicarbazones and thiosemicarbazones," Coordination Chemistry Reviews, vol. 63, pp. 127-160, 1985.

[36] D. X. West, S. B. Padhye, and P. B. Sonawave, "Structural and physical correlations in the biological properties of transition metal heterocyclic thiosemicarbazone and $S$ alkyldithiocarbazate complexes," Structure and Bonding, vol. 76, pp. 1-50, 1991.

[37] A. R. Shahverdi, H. R. Monsef-Esfahani, F. Tavasoli, A. Zaheri, and R. Mirjani, "Trans-cinnamaldehyde from Cinnamomum zeylanicum bark essential oil reduces the clindamycin resistance of Clostridium difficile in vitro," Journal of Food Science, vol. 72, no. 1, pp. S55-S58, 2007. 


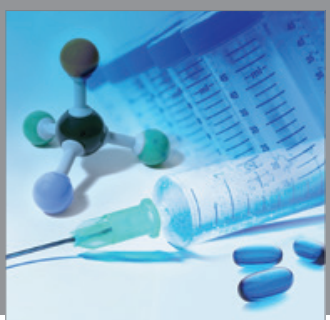

International Journal of

Medicinal Chemistry

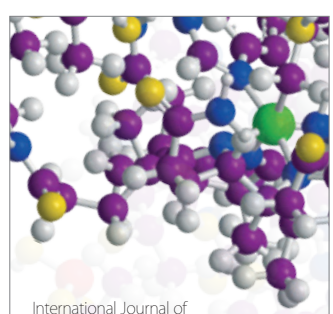

Carbohydrate Chemistry

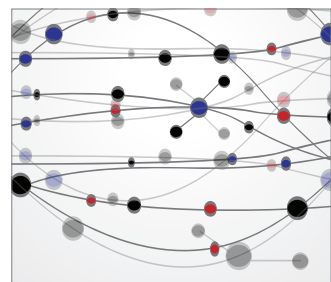

The Scientific World Journal
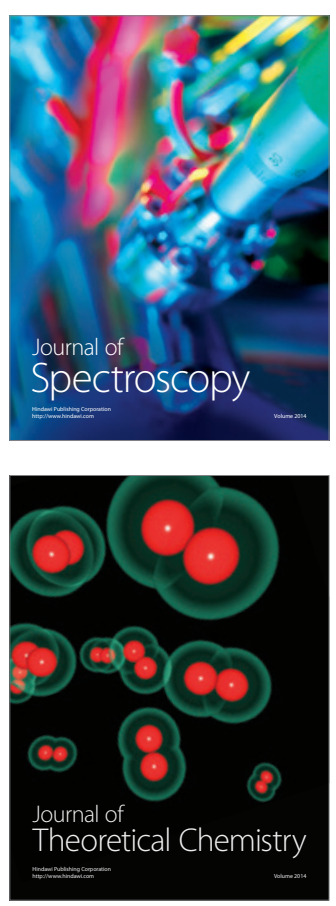
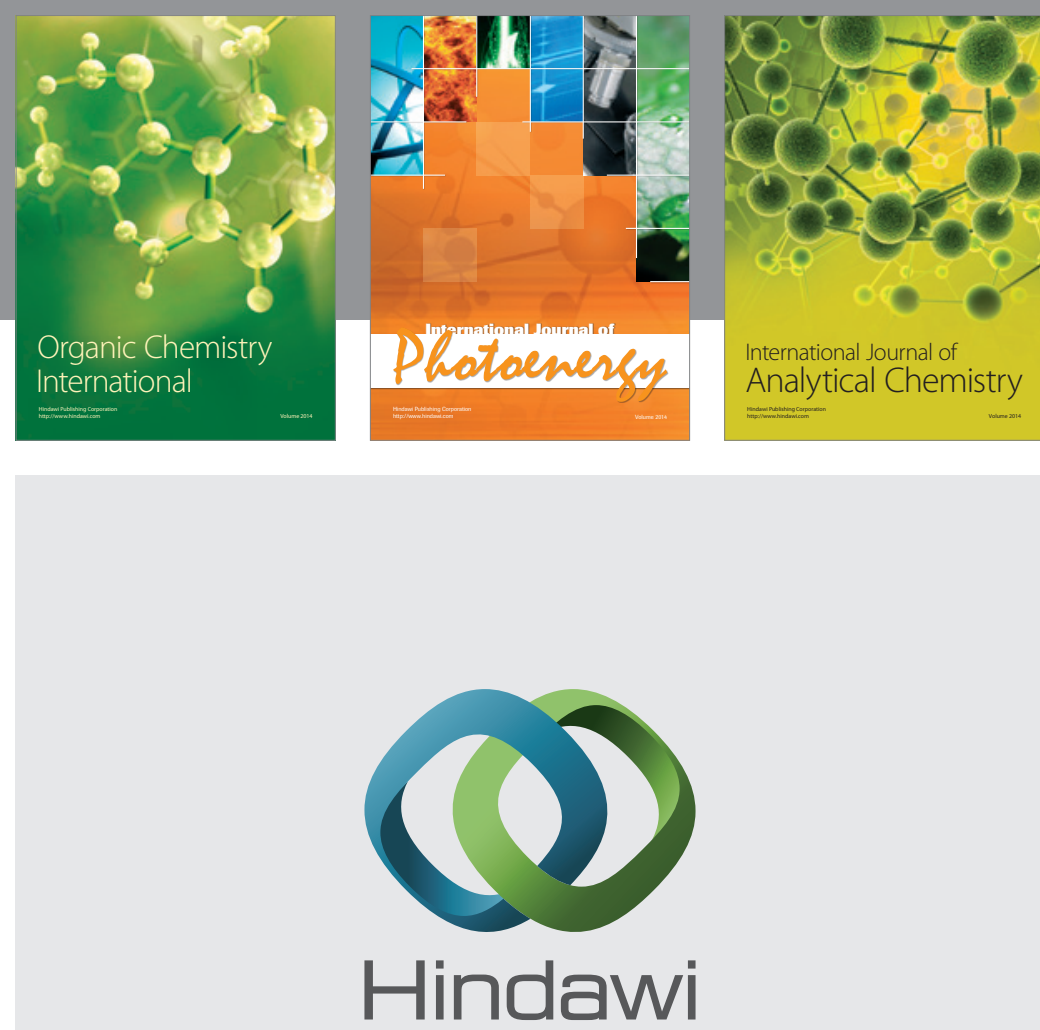

Submit your manuscripts at

http://www.hindawi.com
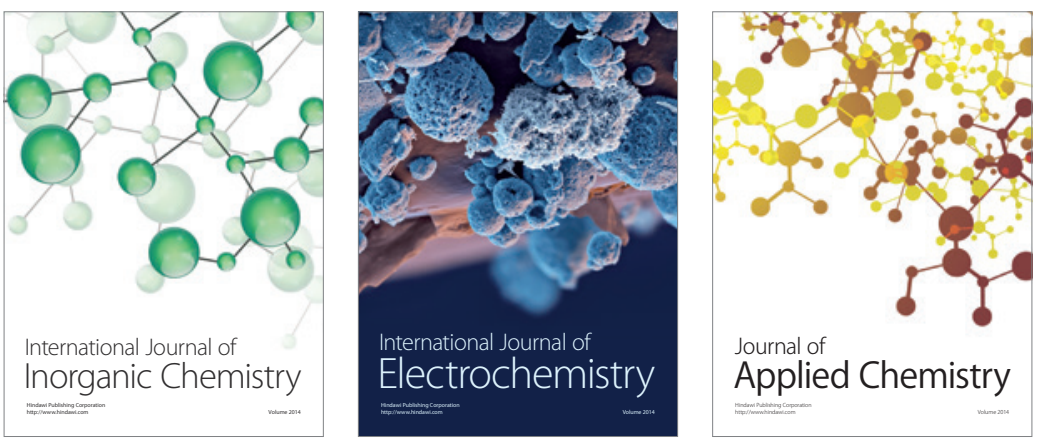

Journal of

Applied Chemistry
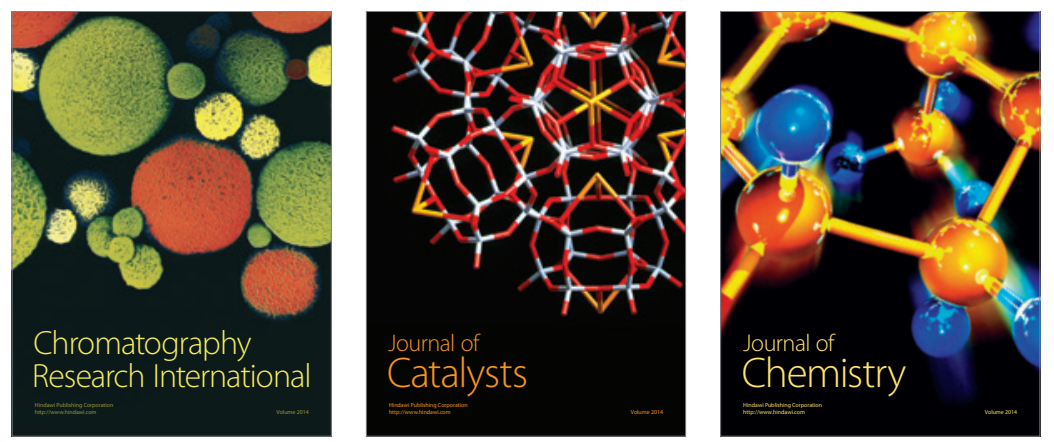
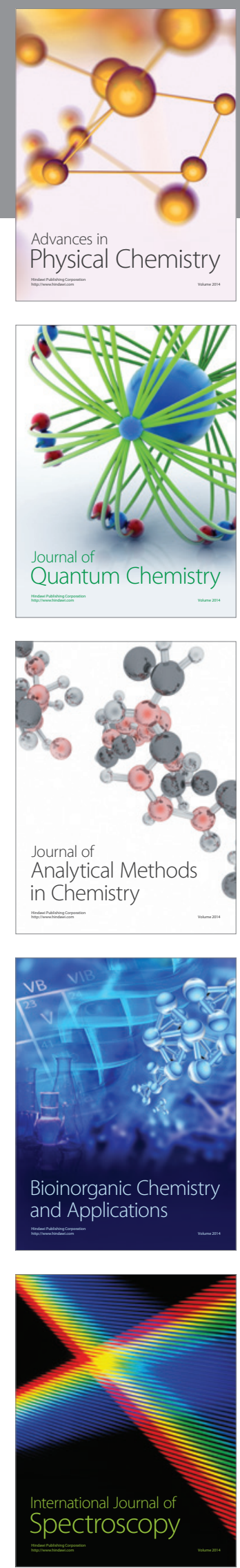